\title{
The Origins of Oceanography in France THE SCIENTIFIC EXPEDITIONS OF TRAVAILLEUR AND TALISMAN (1880-1883)
}

\author{
By John R. Dolan
}

\begin{abstract}
This article describes the earliest French oceanographic expeditions dedicated to investigating the deep sea. Though these expeditions, conducted from 1880 to 1883 , were quite successful in terms of both science and what today we call "outreach," they are often overlooked in histories of oceanography or mentioned only in passing. They produced a substantial literature of over 100 scientific publications. Participants' descriptions of 176 new species are still considered valid today. Among the remarkable scientific discoveries were culturable and pressure-tolerant bacteria in deep-sea sediment samples, which led to the origin of deep-sea microbiology, and iconic deepsea fish such as the gulper eel. Specimens, instruments, and equipment from these expeditions were on display for the general public at an exhibition at the National Museum of Natural History in Paris in early 1884. Between 1885 and 1891, expedition scientists authored three mass-market books on deep-sea life and the expeditions. Following a summary of the expeditions and their results, some speculation is provided as to why such an auspicious nineteenth century beginning of oceanography in France did not lead to a sustained interest in oceanography. A supplementary file contains a bibliography of expedition publications and a list of the species described from expedition collections.
\end{abstract}

\section{THE BEGINNINGS OF SCIENTIFIC STUDY OF THE DEEP SEA}

Development of Scientific Interest in the Deep Sea and British Efforts

Histories of scientific interest in the deep sea often, and curiously, give prominence to a proposition credited to Edward Forbes (1844) that the deep sea was a vast lifeless, or azoic, zone (e.g., Rice et al., 1976). In reality, Forbes reported findings only with regard to the vertical distribution of mollusks and echinoderms in the Aegean Sea based on dredging. He found nothing below a depth of 230 fathoms $(420 \mathrm{~m})$, and his report included a diagram of faunal depth zones that labeled the layer below 300 fathoms "Zero of Animal Life probably about 300 fathoms." He did not propose the depth as a general rule, nor did he use the term "azoic"; it appears only once in passing in the posthumously published book, The Natural History of the European
Seas (Forbes and Godwin-Austen, 1859, pg. 247). Regardless, testing the idea that no life existed at great depths, despite long-standing but scattered evidence to the contrary (as summarized in Carpenter, 1868), provided a marvelous straw man that justified early explorations for deep-sea life. Additionally, there was great interest in the nature of the seabed and physical conditions in the deep sea as attempts were being made to lay undersea telegraph cables. In fact, some of the early discoveries of deep-sea life forms were made through soundings carried out to determine the depth and nature of the seabed in the North Atlantic by the British (e.g., Wallich, 1860) and during retrieval of broken cables in the Mediterranean by the French (e.g., Milne Edwards, 1861).

The proposition of the deep sea as perhaps azoic provided in no small part the justification for the first systematic explorations of the deep sea led by British biolo- gists through the expeditions of Lightning in 1868 and Porcupine in 1869 in the North Atlantic (Thomson, 1873). These first cruises dedicated to dredging the deep sea yielded the conclusions below, presented to the Royal Society of London by William Carpenter, vice president of the society (Carpenter et al., 1870):

1. That the Ocean bottom, at depths of 500 fathoms or more, presents a vast field for research, of which the systematic exploration can scarcely fail to yield results of the highest interest and importance, in regard alike to Physical, Biological, and Geological Science.

2. That the prosecution of such a systematic exploration is altogether beyond the reach of private enterprise, requiring means and appliances which can only be furnished by Government.

These observations led directly to the first large-scale exploration of the sea, the well-known Challenger Expedition of 1872-1876. Preliminary results of the Challenger Expedition appeared relatively quickly and were made widely available in 1878 by the chief scientist, Sir Charles Wyville Thomson, in two volumes under the title The Voyage of the Challenger: The Atlantic: a preliminary account of the general results of the exploring voyage of the H.M.S. Challenger during 1873 and the early part of the year 1876. The complete scientific results were eventually published from 1885 to 1895 in the famous massive series of over 80 monographs, mostly under the guidance of John Murray following Thomson's death in 1882 . 


\section{French Interest in Exploring}

\section{the Deep Sea}

Long-standing French interest in the deep sea is evidenced by Alphonse Milne Edwards's descriptions of organisms attached to the undersea telegraph cables laid between Sardinia and Algeria (Milne Edwards, 1861). In 1867, while Carpenter and Thomson were occupied with planning the Lightning expedition, the Marquis Léopold Folin, harbormaster of the Port of Bayonne, founded the first serial publication dedicated to marine sciences, including one focused on the deep sea: Les Fonds de la Mer (The Bottom of the Sea). A naturalist as well as a harbormaster, Folin specialized in tube-forming mollusks on which he would later contribute to the Challenger Reports (Folin, 1886).

Les Fonds de la Mer was originally printed in 16-page issues of text with plates (Figure 1). The first "volume," composed of issues published from 1867 to 1872 , contained contributions by George S. Brady, who would later contribute to the Challenger Reports (Brady, 1880), and Alphonse Milne Edwards, whose interests included mammals, birds, and crustaceans and who (along with Folin) would later be responsible for the Travailleur and Talisman expeditions. The first issues also contained early citizen science, as Folin reported extensively on diverse samples of deep-sea soundings and sediment types from around the globe sent to him or delivered by the captains or officers of ships, many traveling to or from Bayonne. Issues of the Les Fonds de la Mer appeared irregularly, with the last issues delivered in 1887. While this first marine science serial is very nearly forgotten, it shows that some French scientists had a marked interest in the deep sea well before the Challenger Expedition, and that they maintained close relationships with British scientists who would later be involved in analyzing samples from Challenger.

Since Thomson 's book on the preliminary results of Challenger appeared in 1878 , it is plausible, and even probable,

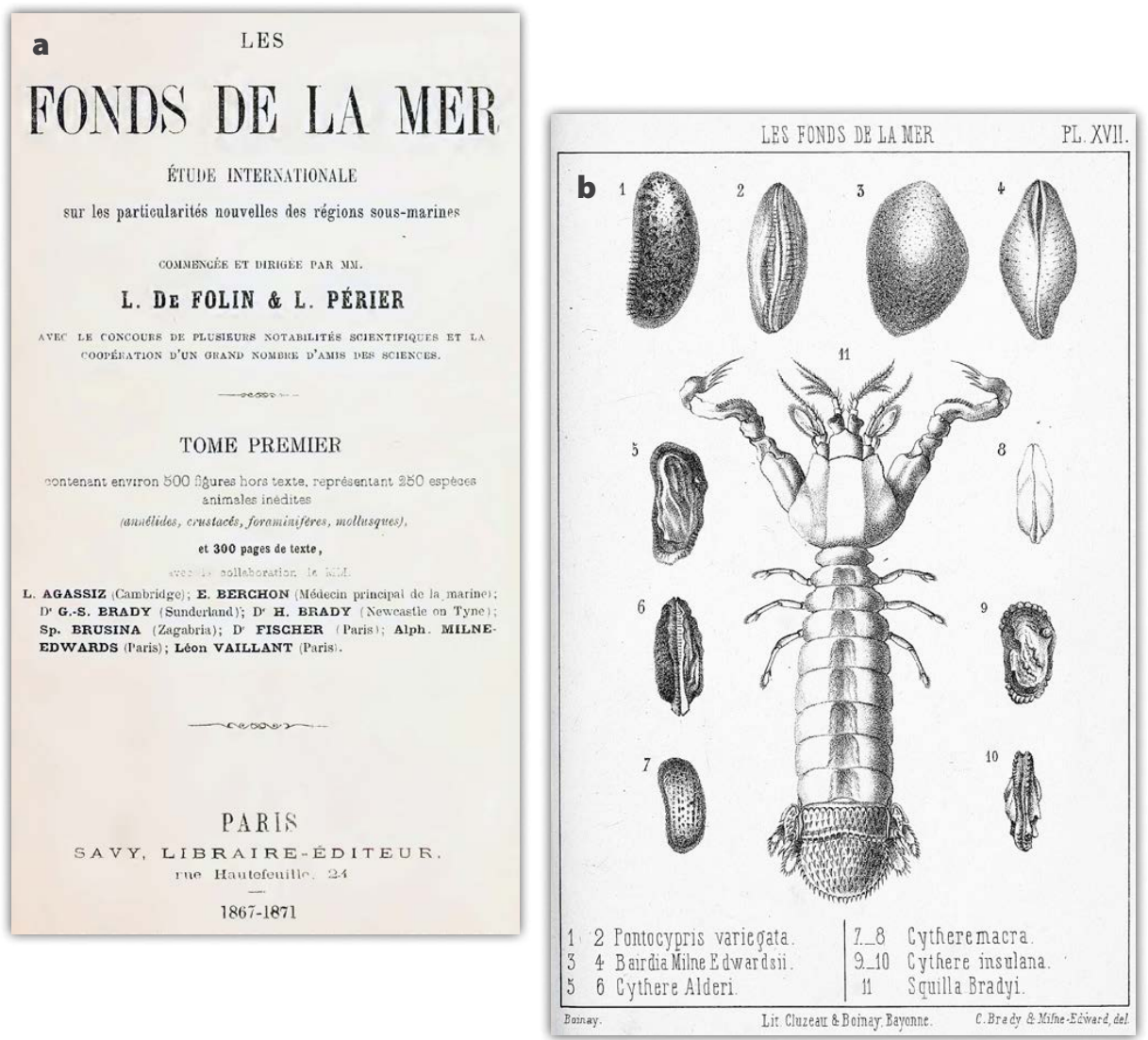

FIGURE 1. (a) The cover of volume one of Les Fonds de la Mer published in issues of 16 pages from 1867 to 1871. (b) Plate 17 from an 1869 article in Les Fonds de la Mer on fauna of Cape Verde with descriptions of new species by George S. Brady and Alphonse Milne Edwards (Folin et al., 1869).

that the success of the British Challenger Expedition prompted, at least in part, Alphonse Milne Edwards to plead in Paris before the Academy of Sciences in 1880 for French expeditions, at the behest of Folin. Milne Edwards had been elected to the academy only the year before at the relatively young age of 43 . He successfully argued for government financing for deep-sea expeditions (Milne Edwards, 1881), as many deep-sea expeditions had been carried out in recent years but none in waters near France or by the French, except for private efforts by himself and Folin. With the support of the Academy of Sciences (roughly the French equivalent of the British Royal Society of London), the Ministry of Education named a commission to organize expeditions to explore the deep sea, headed by invertebrate zoologist Henri Milne-Edwards, and including his son Alphonse, Folin, a number of French zoologists, and also the British scientists John Gwyn Jeffreys (who had been

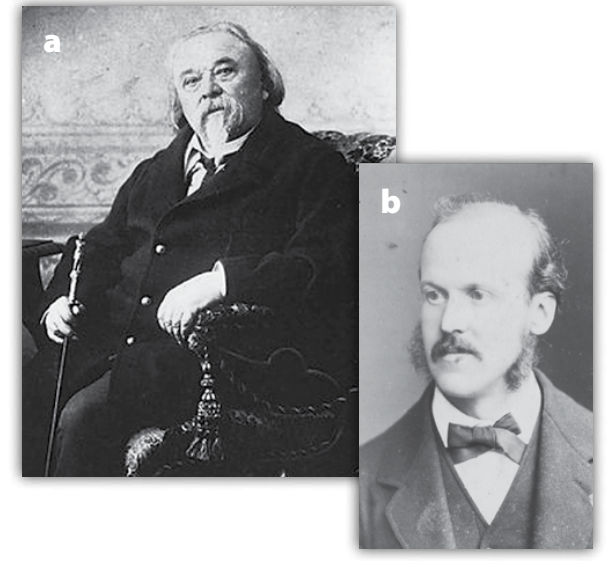

FIGURE 2. The instigators and organizers of (1817-1896) and (b) Alphonse Milne Edwards (1835-1900).

chief scientist aboard Porcupine in 1869) and Alfred Norman. Folin and Alphonse Milne Edwards (Figure 2) obtained the use of a navy steamer, Travailleur, from the Ministry of Maritime Affairs for an expedition to sample the deep sea. the deep-sea expeditions: (a) Leopold Folin 

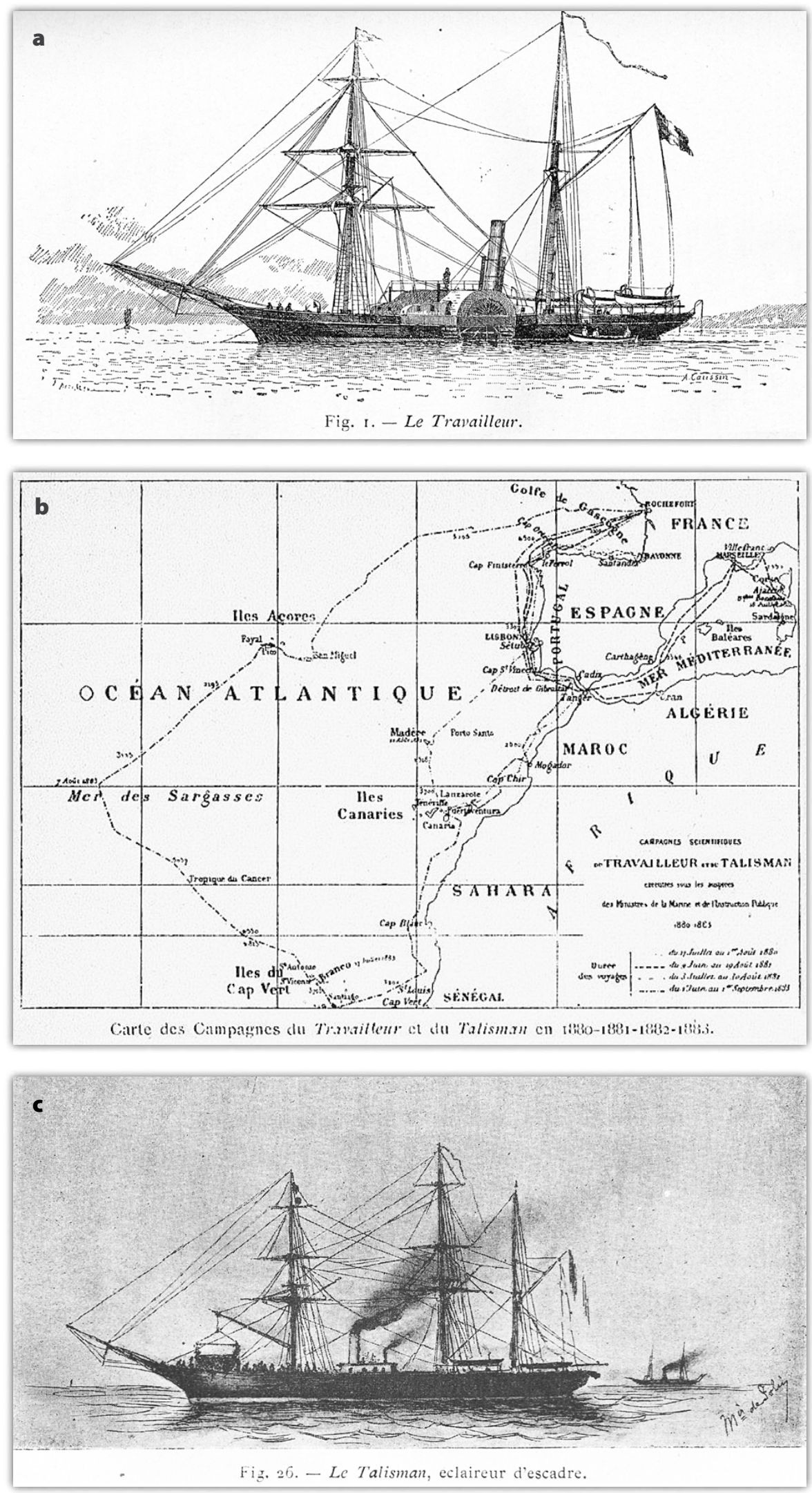

FIGURE 3. (a) The $45 \mathrm{~m}$ long side-wheel steamer Travailleur used in 1880, 1881, and 1882. (b) Cruise tracks of Travailleur and Talisman. (c) The $75 \mathrm{~m}$ long steamer Talisman used in the 1883 cruise. Ship drawings from Folin, 1887, Talisman drawing by Folin, map from Anonymous, $1880-1890$

\section{THE EXPEDITIONS OF TRAVAILLEUR AND TALISMAN}

Travailleur was a $45 \mathrm{~m}$ long side-wheel steamer (Figure 3a), usually with a crew of about 90 , but increased to 128 for the anticipated intensive dredging operations. The dredge used was that designed by the American naturalist Alexander Agassiz: it worked equally well whichever way it fell onto the seabed. The first expedition of two weeks duration in July of 1880 in the Bay of Biscay was basically a shakedown cruise. With 23 dredge hauls made between $300 \mathrm{~m}$ and 2,600 m depth, and 103 soundings, the cruise was a resounding success. Preliminary reports by the two British naturalists aboard Travailleur, Jeffreys and Norman, appeared very quickly, noting findings of new deep-sea forms and even some mollusks thought to be extinct (Jeffreys, 1880; Norman, 1880).

Based on the success of the first cruise, eight weeks of ship time was granted for the following year to explore the depths of the North Atlantic and the Mediterranean. During the second Travailleur expedition in July and August of 1881 , the ship, equipped with $15 \mathrm{~km}$ of cable for dredging and new samplers for taking discrete depth water samples, traveled from Bayonne on the Atlantic coast to the Mediterranean. Mostly sampling in the Northwest Mediterranean Sea (see Figure $3 b$ ), about 50 deepwater dredge hauls were made; the Mediterranean fauna was found to be largely a subset of that known from the depths of the Atlantic, where the deepwater fauna appeared to be much richer. Again, the preliminary scientific results were described as unique and significant (Milne-Edwards, 1882), justifying continuing the explorations the following year.

The third Travailleur cruise lasted the entire months of July and August of 1882 and was dedicated to exploration of the seafloor in the North Atlantic between Bayonne and the islands of Madeira and the Canaries, thus ranging much further offshore than the previous cruises. Dredge hauls were made at 71 stations, again 
bringing up new species. The ship, however, with its limited range, proved to be less than ideal for open-water sampling. The final expedition the following year therefore employed a larger steamer with a longer range of operation, Talisman.

Talisman (Figure 3c) was a $75 \mathrm{~m}$ long vessel equipped with a steam-driven propeller as well a full complement of sails. It sailed from Rochefort (see Figure 3b) on June 1 and returned on August 31, 1883. Sampling was conducted along the Atlantic coasts of Morocco, Sudan, and Senegal, then through the Canaries, the Azores, and out to the edge of the Sargasso Sea. Along the cruise track, 212 soundings and 156 dredge hauls were carried out, some to depths of $5 \mathrm{~km}$. This last cruise with Talisman yielded some of the more spectacular finds such as the iconic deep-sea fish, the gulper eel, and decapod crustaceans with odd morphologies, one named after Talisman (Figure 4). Jeffreys (1884) reported on the Talisman cruise, and the participants were honored by the Academy of Sciences with medals of honor. A popular account of the expedition by Filhol was serialized in the French journal La Nature (Filhol, 1884); excerpts were translated into English and published in installments in the American journal Science (Anonymous, 1884a).

\section{SUMMARY OF THE SCIENTIFIC RESULTS OF THE TRAVAILLEUR AND TALISMAN EXPEDITIONS}

Many new species were described from the material gathered during the expeditions. However, as is often the case, most forms described as new eventually turned out to have been previously described under another name. For example, in his monographic treatment of mollusks from the expeditions, Locard (1897-1898) described 163 forms as new, and of those, only 56 are currently credited as valid original descriptions. Likewise, only 7 of the 70 species of bryozoans described as new by Calvet (1906) are currently credited to him. Nonetheless, a large number, at least 176 species descriptions based on expedition material, are still recognized
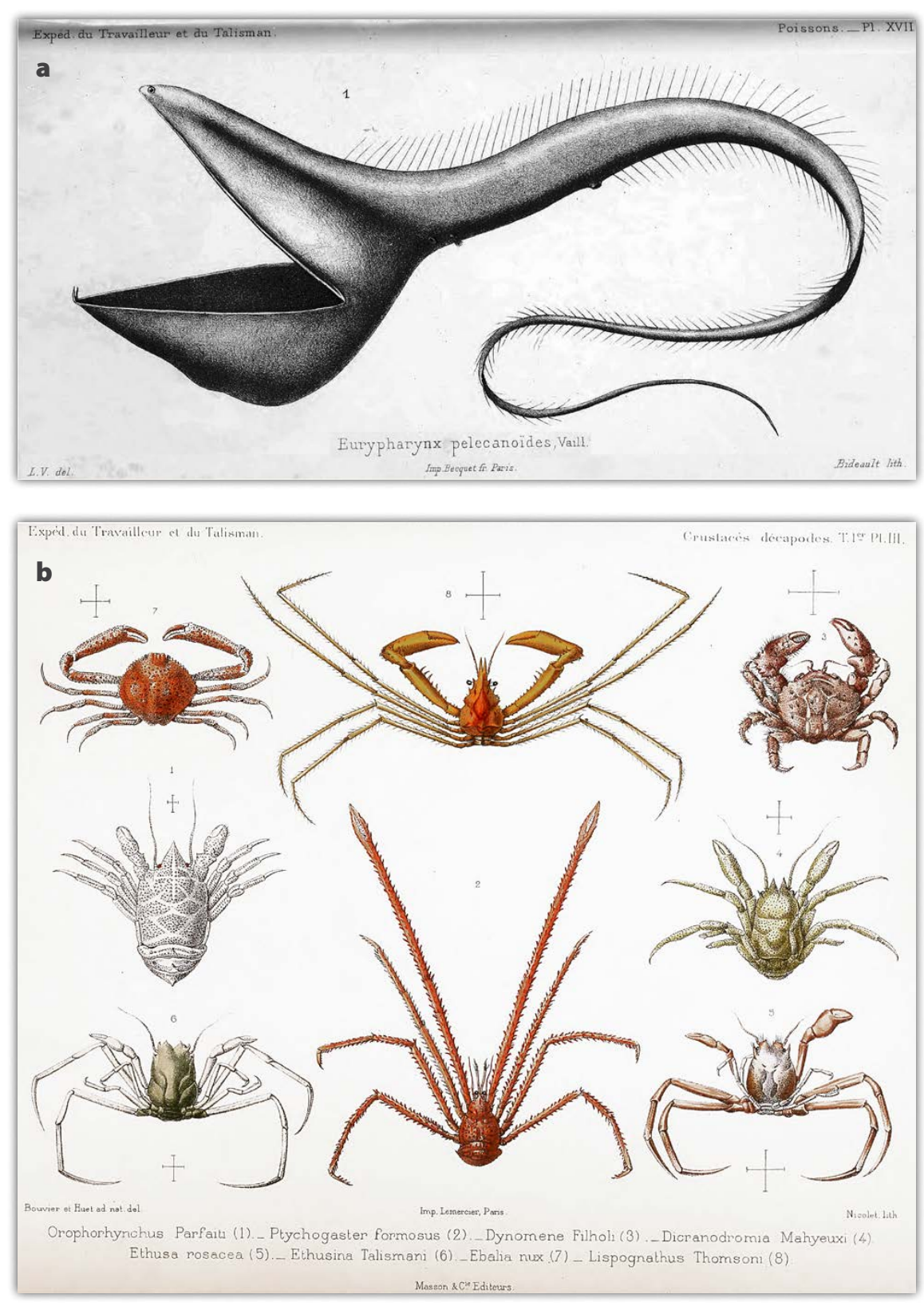

FIGURE 4. The surprising morphologies of deep-sea fauna found during the expeditions. (a) The iconic deep-sea fish, the gulper eel. (b) Deep-sea crustaceans, including a new species named for Talisman, Ethusina talismani.

as valid. This estimate is conservative as it is not always clear from the descriptions if the specimens used were from the expeditions or from other collections (e.g., Milne Edwards and Bouvier, 1900). Most of the new forms found were benthic macrofauna, shelled mollusks, echinoderms, and crustaceans (Figure 5).

A substantial literature concerning the expeditions themselves, or the material collected, was produced totaling at least 126 works. It is probable that my searches did not uncover all the publications, but of those found, almost half concern the benthic megafauna, mirroring to a large extent the descriptions of new species (Figure 5). In addition, there were also technical accounts: cruise narratives destined for a professional audience (e.g., geographers) and official cruise accounts (e.g., for the Maritime Ministry). The most cited publications (according to Google Scholar) are those on the taxonomic groups, with many new 
species described, again mollusks and crustaceans. Exceptions are well-cited publications that describe bacteria cultured from deep Mediterranean Sea sediment samples collected during the 1881 Travailleur expedition and early experiments examining the tolerance of a variety of microbes for high pressure, like that of the deep sea. The papers by Adrian Certes (1884a,b; Certes and Cochin 1884), based on work he carried out in the laboratory of Louis Pasteur, are well recognized as the beginnings of deep-sea microbiology (e.g., Zobell, 1952; Jannasch and Taylor, 1984; Levin and Gooday, 2003; Bartlett,
2008; Adler and Dücker, 2018). Thus, ironically, the scientific results of the expeditions of Travailleur and Talisman likely are better known to microbiologists than to oceanographers.

\section{POPULARIZATION OF THE DEEP SEA BY EXPEDITION PARTICIPANTS}

Just a few months after Talisman returned to its homeport of La Rochelle, a large public exhibition was installed in the National Museum of Natural History in Paris: L'Exposition Sous-Marine $d u$ Travailleur et $d u$ Talisman (The Undersea Exhibition

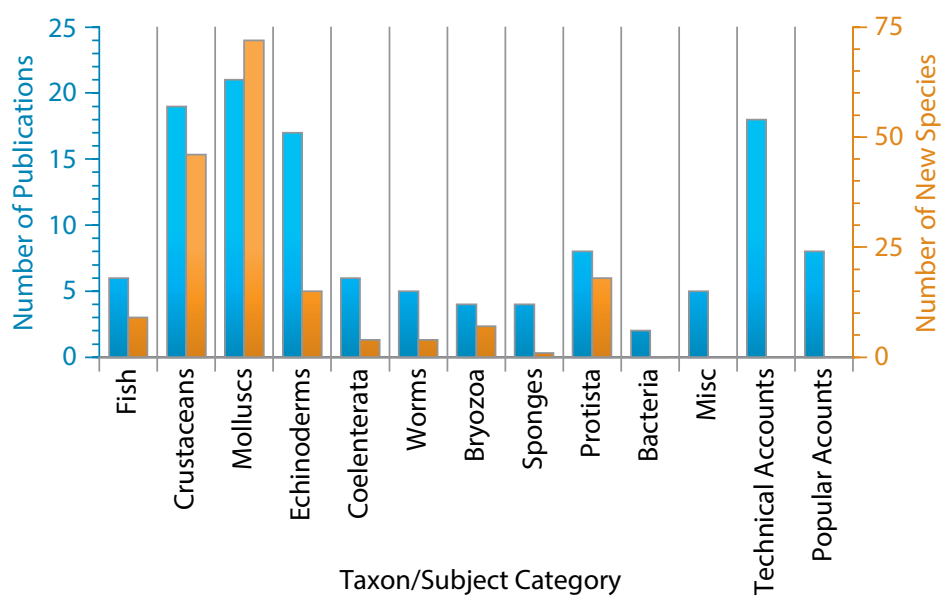

FIGURE 5. Numbers of new species described from expedition material pooled into large taxonomic groups and numbers of expedition publications pooled by subject. of the Travailleur and Talisman). Organized by Milne Edwards with other staff of the museum's Laboratory of Zoological Anatomy and Physiology, the exhibition was opened with great ceremony by the Minister of Education in the company of a variety of politicians and the captains of both Travailleur and Talisman, as well as all the museum professors (Anonymous, 1884b). From January to March 1884, the public was invited to admire not only specimens of the odd fauna found but also to examine for themselves some of the instruments and equipment used to explore the deep sea (Figure 6). The exhibit was enormously successful, described as drawing crowds not previously seen at the museum (Lacroix, 1926). The exhibition appears to be one of the earliest efforts of outreach in oceanography.

In addition to the exhibition, the expedition participants also wrote books, aimed at general audiences, about the deep sea in general and the expeditions in particular. The first and most spectacular to appear, as it included four color plates (e.g., Figure 7), was by Henry Filhol in 1885, La Vie au Fonds Des Mer: Les explorations sous-marines et les voyages $d u$ Travailleur et $d u$ Talisman (Life at the bottom of the sea: The under-sea explorations and voyages of the Travailleur
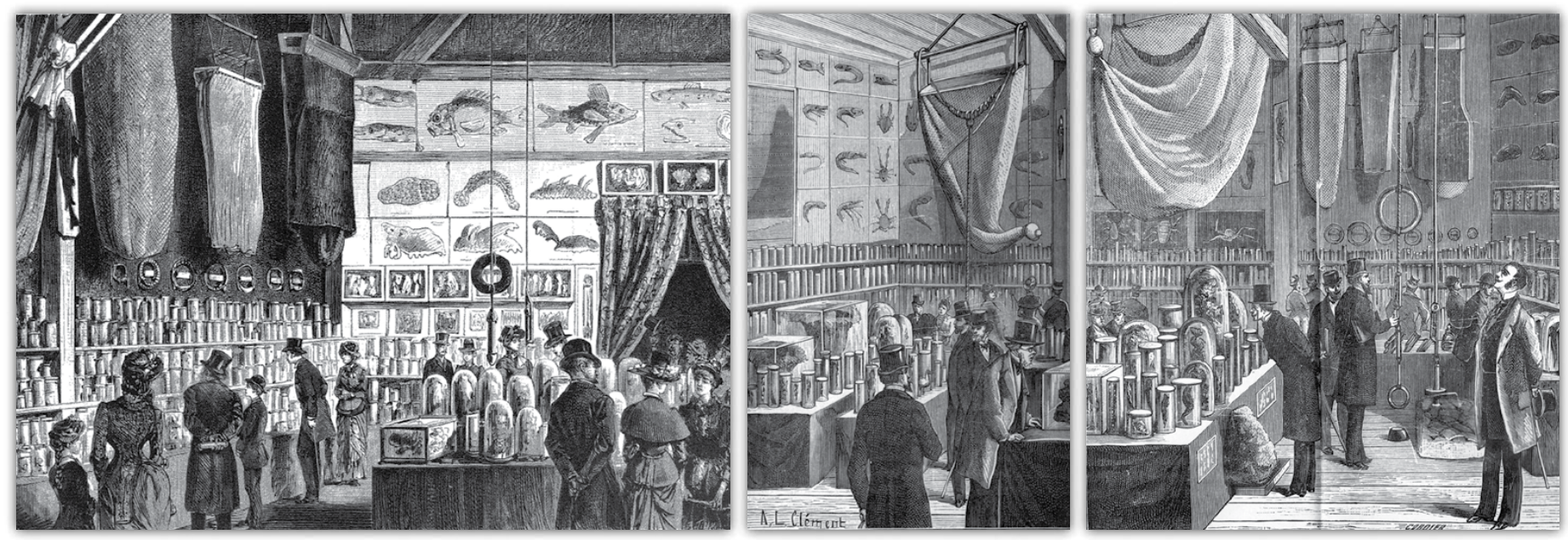

FIGURE 6. Illustrations show scenes of L'Exposition Sous-Marine du Travailleur et du Talisman, which ran at the National Museum of Natural History (Paris) from January 26 to March 16, 1884. The exhibition included specimens and illustrations of deep-sea fauna as well as, importantly, the equipment and instruments used in oceanographic studies. Thus, the exhibit displayed not only the deep-sea creatures found but also how the creatures were found. Illustrations from Filhol, 1884, and Dollo, 1891 
and of the Talisman). Henry Filhol would later hold the Chair of Comparative Anatomy at the Museum of Natural History and be elected to the French Academy of Sciences.

The second book, by Edmond Perrier, subsequently to become the director of the National Museum of Natural History, was published a year later, in 1886. From its title, Les Explorations Sous-Marin (Undersea Explorations), the book was clearly not focused exclusively on the Travailleur and Talisman expeditions nor on the deep sea. But, as noted in the preface, Perrier relied considerably on the expeditions' results and the contributions of other cruise participants, including both Folin and Filhol. Second and third editions were published in 1891 and 1899 (Perrier, 1891, 1899). The third popular book appeared in 1887: Sous les Mers: Campagnes d'explorations $d u$ Travailleur et $d u$ Talisman (Under the Sea: The campaigns of exploration of the Travailleur and of the Talisman) by the instigator of the expeditions, Léopold Folin. By then age 70, Folin dedicated the book to his grandson "hoping he also will be interested in the study of the sea" (Folin, 1887). The fact that these books appeared in such quick succession (i.e., 1885, 1886, 1887,1891 , and 1899) suggests that the publishers found a solid market for popular books on the deep sea.

\section{NEGLECT OF THE EXPEDITIONS DUE TO THE SLOW DEVELOPMENT OF OCEANOGRAPHY IN FRANCE?}

The Travailleur and Talisman expeditions were scientific and public relations successes, an auspicious beginning to oceanography in France. However, with the singular exception of Saldanha (2002), in accounts of the history of oceanography, they are either mentioned only in passing (e.g., Deacon, 1971; Menzies et al., 1973) or neglected (e.g., Wüst, 1964; Sears and Merriman, 1980) as pointed out by Mills (1983). This is likely due, at least in part, to the fact that the expeditions were not followed by sustained

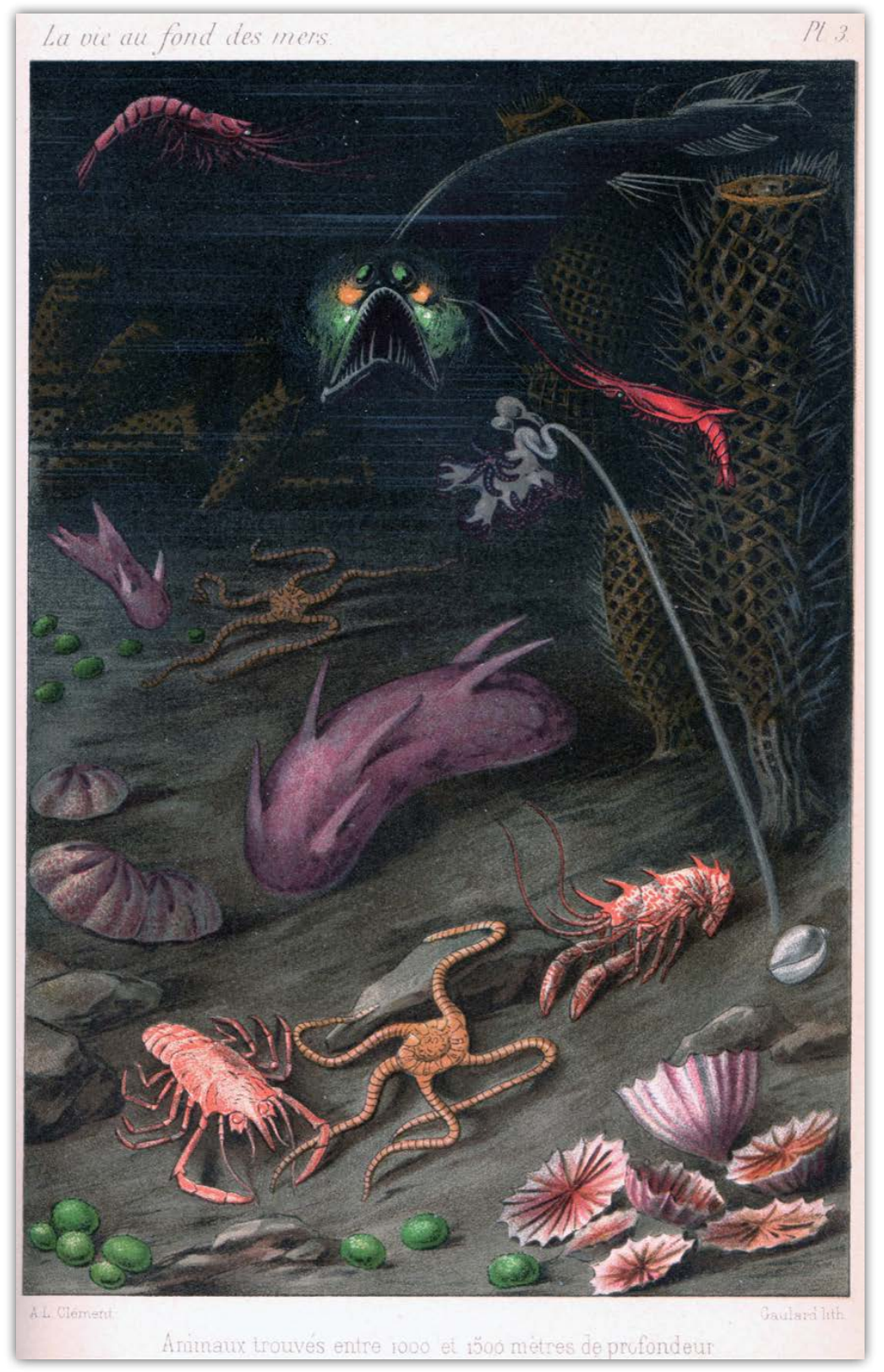

FIGURE 7. Plate 2 of La Vie au Fonds des Mer: Les explorations sous-marines et les voyages du Travailleur et $d u$ Talisman (Life at the bottom of the sea: The undersea explorations and voyages of the Travailleur and of the Talisman; Filhol, 1885) depicts organisms from depths between 1,000 $\mathrm{m}$ and 1,500 m.

development of oceanography in France. This was largely true until the 1960s. This is not to say that there were no French oceanographic expeditions; there were, for example, the early twentieth century voyages of Jean-Baptist Charcot to the Arctic and Antarctic, but they were conducted without the direct support of governmental agencies (Laubier, 1992). Meanwhile in other countries, such as the United States, Germany, and the United Kingdom, oceanography grew rapidly in the first half of the twentieth century with the establishment by the 1930s of oceanographic institutions and graduate programs in oceanography (Vaughn, 1937). Admittedly, assessing why oceanography failed to develop similarly in France is largely speculation. Nonetheless, a few non-exclusive explanations can be offered.

One factor may have been a lack of scientists of stature advocating for oceanography. The instigators of the expedi- 
tions, Folin and Milne Edwards, both died by 1900 . Although the other scientists involved eventually acquired considerable stature, they were classic zoologists working on a variety of taxa and not focused on studies of the sea. There were no French personalities comparable to John Murray in the United Kingdom, Alexander Agassiz in the United States, Johan Schmidt in Denmark, or Victor Hensen in Germany. Another possible factor is that the oceanographic institute created by the Prince of Monaco in Paris, along with his voyages (which furnished specimens for researchers in France), reduced impetus and need for the establishment of a French oceanographic institution. Ironically, the Prince of Monaco is said to have been greatly inspired to create the Museé Océanographique in Monaco by the Travailleur and Talisman exhibition at the National Museum of Natural History (Carpine-Lancre, 2001). The Institute Océanographique in Paris employed some research staff, and classes were given, but it did not confer diplomas.

Another aspect is that marine science in France was, by the early 1900s, overwhelmingly dominated by marine biologists working on littoral habitats in a large number of marine stations, part of what Antony Adler (2019) termed "The Marine Station Movement." Charles Kofoid's 1910 book, The Biological Stations of Europe, listed 14 marine stations in France (excluding fisheries laboratories) compared to eight in the United Kingdom and only three in Germany. Thus, in France, there was a relatively large population of shore-based biologists perhaps nearly monopolizing available resources. Eric Mills (2009) discussed "the failure of French oceanography" and pointed out that for a variety of reasons, French physical oceanographers in the early 1900s were few in number and appear to have been isolated from scientific currents in other countries. Regardless of the reasons, oceanography, although today quite strong, was undeniably slow to develop in France.

The first French vessel specifically built for deepwater oceanographic work was Président Théodore Tissier in 1933 (Le Danois, 1948), but by 1938 it was transferred to the merchant marine for use as a training vessel. In the Cold War era, the strong ties of ocean scientists with the navy that characterized the development of oceanography in the United States (i.e., the Office of Naval Research) apparently did not exist in France. It was not until 1968 that another deepwater oceanographic vessel, Jean Charcot, was launched; the vessel was described as "designed with the ambition of allowing our country to recover its place among the leading nations of oceanography" (Laubier, 1985). Some of the first oceanographic campaigns of both Président Théodore Tissier and Jean Charcot were dedicated to sampling the benthos of the Bay of Biscay (Le Danois, 1948; Laubier, 1985) as was the first expedition of Travailleur. Although courses in ocean sciences were offered in the universities, degree programs were not created in France until the late 1960s, at about the same time that the national science organization, the Centre National de la Recherche Scientifique (the largest employer of research scientists in France), formally recognized oceanography as a distinct scientific discipline (Geistdoerfer, 2015).

\section{CONCLUSION}

On the heels of the Challenger Expedition, the early French deep-sea explorations of Travailleur and Talisman, while not of the same magnitude as the Challenger Expedition, uncovered a large number of novel organisms, including the first deep-sea bacteria and the ever-popular gulper eel (e.g., https://www.youtube. com/watch?v=iT_EMK12A3Y). The scientists involved in the explorations produced not only a considerable number of scientific publications, many still cited today, but also a museum exhibition, articles in the popular press, and several general audience books, all on the deep sea. Despite their scientific and popular successes, the Travailleur and Talisman voy- ages are rarely remembered. I hope that, with the story told here of the remarkable expeditions of Léopold Folin and Alphonse Milne Edwards, they will perhaps be less neglected. [

\section{SUPPLEMENTARY MATERIALS}

A file containing lists of publications from the expeditions and of species described from expedition material, currently recognized as valid first descriptions, is available online at https://doi.org/10.5670/ oceanog.2020.202.

\section{REFERENCES}

Adler, A. 2019. Neptune's Laboratory: Fantasy, Fear, and Science at Sea. Harvard University Press, Cambridge MA, $241 \mathrm{pp}$.

Adler, A., and E. Dücker. 2018. When Pasteurian science went to sea: The birth of marine microbiology. Journal of the History of Biology 51:107-138, https://doi.org/10.1007/s10739-017-9477-8.

Anonymous. 1880-1890. Cahiers d'enseignement illustrés. no 4: Explorations sous-marines du Travailleur et du Talisman. L. Bashet, Paris, $16 \mathrm{pp}$.

Anonymous. 1884a. The deep-sea dredging apparatus of the Talisman; The deep-sea fishes collected by the Talisman; The deep-sea crustacea dredged by the Talisman; The echinoderms dredged by the Talisman. Science, 3:448-455; 3:623-628; 3:713-716; 4:102-105.

Anonymous. 1884b. Un monde sous-marin. Le Temps, number 8314, February 1, 1884, p. 2.

Bartlett, D.H. 2008. Introduction to deep-sea microbiology. Pp 195-201 in High Pressure Microbiology. C. Michaels, D.H. Bartlett, and A. Aertsen, eds, American Society for Microbiology, Washington, DC.

Brady, G.S. 1880. Report on the Ostracoda dredged by H.M.S. Challenger during the years 1873-1876. Pp. 1-184 in Report on the Scientific Results of the Voyage of H.M.S. Challenger. Zoology, Volume 1.

Calvet, L. 1906. Bryozoaires. PP. 355-495 in

Expéditions scientifiques du 'Travailleur' et du 'Talisman' pendant les années 1880, 1881, 1882, 1883, vol. 7.

Carpenter, W.B. 1868. Preliminary report of dredging operations in the seas to the North of the British Islands, carried on in Her Majesty's Steamvessel Lightning by Dr. Carpenter and Dr. Wyville Thomson. Proceedings of the Royal Society of London 17:168-200, https://doi.org/10.1098/ rspl.1868.0026.

Carpenter, W.B., J.G. Jeffreys, and C.T.W. Thomson. 1870. Preliminary report of the scientific exploration of the deep sea in HM surveying-vessel Porcupine, during the summer of 1869. Proceedings

of the Royal Society of London 18:397-492, https://doi.org/10.1098/rspl.1869.0084.

Carpine-Lancre, J. 2001. Oceanographic sovereigns: Prince Albert I of Monaco and King Carlos I of Portugal. Pp. 56-68 in Understanding the Oceans. M. Deaco, T. Rice, and C. Summerhayes, eds, UCL Press, London.

Certes, A. 1884a. Sur la culture, à l'abri des germes atmosphériques, des eaux et des sédiments rapportés par les expéditions du Travailleur et du Talisman. Comptes Rendue Hebdomadaire des Séances de l'Académie des Sciences 98:690-693.

Certes, A. 1884b. Note relative à l'action des hautes pressions sur la vitalité des microorganismes d'eau douce et d'eau de mer. Comptes Rendue Hebdomadaire des Séances de l'Académie des Sciences 99:385-388. 
Certes, A., and D. Cochin. 1884. Action des hautes pressions sur la vitalité de la levure et sur les phenomenes de la fermentation. Comptes Rendue Hebdomadaires des Séances et Mémoires de la Sociéte de Biologie, Série 8, n 36:639-640.

Deacon, M. 1971. Scientists and the Sea 1650-1900: A Study of Marine Science. Aberdeen University Press, Aberdeen, UK, $445 \mathrm{pp}$

Dollo, L. 1891. La Vie au Sein des Mers: La faune marine et les grandes profondeurs, les grandes explorations sous marin, les conditions d'existence dans l'abysses, la faune abyssale. Librairie J.-B. Baillière et Fils, Paris, 300 pp.

Filhol, H. 1884. Explorations sous-marines, Voyage du "Talisman". La Nature, Year 12, 119-122, 134-138, 147-151, 161-164, 182-186, 198-202, 230-234, 278-282, 391-394.

Filhol, H. 1885. La vie au fonds des mers: les explorations sous-marine et les voyages due "Travailleur" et du "Talisman." Paris, Masson, $301 \mathrm{pp}$.

Folin, L. 1886. Appendix B. Report on the Caecidae collected by H.M.S. Challenger during the years 1873-76. In Report on the Scientific Results of the Voyage of H.M.S. Challenger During the Years 1873-1876. Zoology 15:681-689.

Folin, L. 1887. Sous les mers Campagnes d'explorations du "Travailleur" et du "Talisman." Libraire J.-B. Baillière et Fils, Paris, 340 pp.

Folin, L., G.S. Brady, and A. Milne-Edwards. 1869. La rade de Saint-Vincent du Cap-Vert (supplément). Les Fonds de la Mer 1:136-146.

Forbes, E. 1844. Report on the Mollusca and Radiata of the Agean Sea, and on their distribution, considered as bearing on Geology. Pp. 130-193 in Report of the Thirteenth Meeting of the British Association for the Advancement of Science, Cork, August 1883

Forbes, E., and R. Godwin-Austen. 1859. The Natural History of the European Seas. John Van Voorst, London, $306 \mathrm{pp}$.

Geistdoerfer, P. 2015. Histoire de l'océanographie: De la surface aux abysses. Nouveau Monde Editions, Paris, $235 \mathrm{pp}$

Jannasch, H.W., and C.D. Taylor. 1984. Deepsea microbiology. Annual Review of Microbiology 38:487-514, https://doi.org/10.1146/ annurev.mi.38.100184.002415.

Jeffreys, J.G. 1880. The deep-sea Mollusca of the Bay of Biscay. The Annals and Magazine of Natural History 6:315-319.

Jeffreys, J.G. 1884. The French deep-sea expedition of 1883. Nature 29:216-217, https://doi.org/ 10.1038/029216b0.

Kofoid, C.A. 1910. The Biological Stations of Europe. United States Bureau of Education, Bulletin No. 4 Whole Number 400. Government Printing Office, Washington, DC, 360 pp.

Laubier, L. 1985. Le program Biogas. Pp. 13-24 in Peuplements Profonds du Golfe de Gascogne. L. Laubier and C. Monniot, eds, Ifremer, Paris, 629 pp.

Laubier, L. 1992. Vingt mille vies sous la mer. Editions Odile Jacob, Paris, $332 \mathrm{pp}$.

Lacroix, A. 1926. Notice historique sur Alphonse Milne Edwards. Mémoires de l'Academie des Sciences de L'Institut de France 58:I-LXXIV.

Le Danois, E. 1948. Les Profondeurs de la Mer: Trente ans de recherches sur la faune sou-marine au large des côtes de France. Payot, Paris, 303 pp.

Levin, L.A., and A. Gooday. 2003. The deep Atlantic Ocean. Pp 111-178 in Ecosystems of the Deep Oceans. P.A. Tyler, ed., Elsevier, Amsterdam.

Locard, A. 1897-1898. Mollusques testacés.

Expéditions scientifiques du Travailleur et du Talisman pendant les Années 1880, 1881, 1882, et 1883, Masson. vol. 1 [1897], p. 1-516; vol. 2 [1898], p. $1-515$.
Menzies, R.J., R.Y. George, and G.T. Rowe. 1973. Abyssal Environment and Ecology of the World Oceans. John Wiley \& Sons, New York, 488 pp.

Mills, E.L. 1983. Problems of deep-sea biology: An historical perspective. Pp 1-79 in The Sea. G.T. Rowe, ed., John Wiley \& Sons, San Francisco.

Mills, E.L. 2009. The Fluid Envelope of Our Planet: How the Study of Currents Became a Science. University of Toronto Press, Toronto, $433 \mathrm{pp}$.

Milne Edwards, A. 1861. Observations sur l'existence de divers mollusques et zoophyes à de très grandes profondeurs dans la Mer Méditerranée. Annales des Sciences Naturelles, Serie 4, Zoologie 15:149-157.

Milne Edwards, A. 1881. Rapport sur les travaux de la commision chargé par M. le Ministre de I'Instruction Publique d'étudier la faune sousmarine dans les grandes profoneurs du Golfe de Gascogne. Archives des Missions Scientifiques et Littéraires 7:421-431.

Milne-Edwards, A. 1882. Les explorations sousmarines du Travailleur dans l'Océan Atlantique et dans la Méditerranée en 1880 et 1881 . Bulletin de la Sociéte de Géographie 3:93-130.

Milne Edwards, A., and Bouvier, E.L. 1900. Heterocarpus grimaldii, espèce nouvelle recueillie par le "Talisman," "l'Hirondelle" et la "Princesse Alice." Bulletin de la Société Zoologique de France 25:58

Norman, A.M. 1880. Notes on the French explorations of "Le Travailleur" in the Bay of Biscay. Annals and Magazine of Natural History 36:430-436.

Perrier, E. 1886. Les Explorations Sous-Marines. Hachette, Paris, $352 \mathrm{pp}$.

Perrier, E. 1891. Les Explorations Sous-Marines, $2^{\text {nd }}$ ed. Paris, Hachette, $352 \mathrm{pp}$.

Perrier, E. 1899. Les Explorations Sous-Marines, $3^{\text {rd }}$ ed. Paris, Hachette, $352 \mathrm{pp}$.

Rice, A.L., H.L. Burstyn, and A.G.E. Jones. 1976. G.C. Wallich M.D. - megalomanic or mis-used oceanographic genius? Journal of the Society for the Bibliography of Natural History 7:423-450, https://doi.org/10.3366/jsbnh.1976.7.4.423.

Saldanha, L. 2002. The discovery of the deep-sea Atlantic fauna. Pp. 235-247 in Oceanographic History: The Pacific and Beyond. K.R. Benson and P.F. Rehbock, eds, University of Washington Press, Seattle.

Sears, M., and D. Merriman, eds. 1980. Oceanography: The Past. Springer-Verlag, New York, $812 \mathrm{pp}$.

Thomson, C.W. 1873. The Depths of the Sea: An Account of the General Results of the Dredging Cruises of H.M.S.S. Porcupine and Lightning During the Summer of 1868, 1869, and 1870, Under the Scientific Direction of Dr. Carpenter, F.R.S., J. Gwyn Jeffreys, F.R.S., and Dr. Wyville Thomson, F.R.S Macmillan, London, $527 \mathrm{pp}$

Thomson, C.W. 1878. The Voyage of the Challenger: The Atlantic: A preliminary Account of the General Results of The Exploring Voyage of H.M.S. Challenger During the Year 1873 and the Early Part of the Year 1876. Harper, New York, vol. 1, 391 pp., vol. 2, $340 \mathrm{pp}$.

Vaughan, T.W. 1937. International Aspects of Oceanography. Oceanographic Data and Provisions for Oceanographic Research. National Academy of Sciences, Washington, DC, 225 pp.

Wallich, G.C. 1860. Notes on the Presence of Animal Life at Vast Depths in the Sea; With Observations on the Nature of the Sea Bed, as Bearing on Submarine Telegraphy. Taylor and Francis, London, $38 \mathrm{pp}$.

Wüst, G. 1964. The major deep-sea expeditions and research vessels 1873-1960: A contribution to the history of oceanography. Progress in Oceanography 2:1-52, https://doi.org/10.1016/ 0079-6611(64)90002-3.
Zobell, C.E. 1952. Bacterial life at the bottom of the Philippine Trench. Science 115:507-508, https://doi.org/10.1126/science.115.2993.507.

\section{ACKNOWLEDGMENTS}

I am grateful to the editor for her patience. The remarks of Antony Adler, Robert Carney, Eric Mills, an anonymous reviewer, but most especially Tony Rice, on previous versions led to great improvements in the manuscript. However, I retain full responsibility for all errors of fact and interpretation.

\section{AUTHOR}

John R. Dolan (dolan@obs-vlfr.fr) is a research scientist at the Laboratoire d'Océanographie de Villefranche-sur-Mer, Sorbonne Université CNRS UMR 7093, Villefranche-sur-Mer, France.

\section{ARTICLE CITATION}

Dolan, J.R. 2020. The origins of oceanography in France: The scientific expeditions of Travailleur and Talisman (1880-1883). Oceanography 33(2):126-133, https://doi.org/10.5670/oceanog.2020.202.

\section{COPYRIGHT \& USAGE}

This is an open access article made available under the terms of the Creative Commons Attribution 4.0 International License (https://creativecommons.org/ licenses/by/4.0/), which permits use, sharing, adaptation, distribution, and reproduction in any medium or format as long as users cite the materials appropriately, provide a link to the Creative Commons license, and indicate the changes that were made to the original content. 